\title{
1000 year ice-core records from Berkner Island, Antarctica
}

\author{
Robert MUlvaney, ${ }^{1}$ Hans OERTER, ${ }^{2}$ David A. PEEL,${ }^{1}$ Wolfgang GRAF, ${ }^{3}$ Garol ARroWSMith, ${ }^{4}$ \\ Elizabeth C. PASTEUR, ${ }^{1}$ Bruge KNIGHT, ${ }^{1}$ Geneviève C. LITTOT, ${ }^{1}$ William D. MiNeRS ${ }^{1 *}$ \\ ${ }^{1}$ British Antarctic Survey, Natural Environment Research Council, Madingley Road, Cambridge CB3 OET, England \\ E-mail: r.mulvaney@bas.ac.uk \\ ${ }^{2}$ Alfred-Wegener-Institut für Polar- und Meeresforschung, Postfach 12061, D-27515 Bremerhaven, Germany \\ ${ }^{3}$ GSF-Forschungszentrum für Umwelt und Gesundheit, Postfach 1129, D-85758 Neuherberg, Germany \\ ${ }^{4}$ Isotope Geosciences Laboratory, Natural Environment Research Council, Keyworth, Nottingham NG12 5GG, England
}

\begin{abstract}
Two medium-depth ice cores were retrieved from Berkner Island by a joint project between the Alfred-Wegener-Institut and the British Antarctic Survey in the 1994/95 field season. A $151 \mathrm{~m}$ deep core from the northern dome (Reinwarthhöhe) of Berkner Island spans 700 years, while a $181 \mathrm{~m}$ deep core from the southern dome (Thyssenhöhe) spans approximately 1200 years. Both cores display clear seasonal cycles in electrical conductivity measurements, allowing dating by annual-layer counting and the calculation of accumulation profiles. Stable-isotope measurements (both $\delta^{18} \mathrm{O}$ and $\delta \mathrm{D}$ ), together with the accumulation data, allow us to estimate changes in climate for most of the past millennium: the data show multi-decadal variability around a generally stable long-term mean. In addition, a full suite of major chemistry measurements is available to define the history of aerosol deposition at these sites: again, there is little evidence that the chemistry of the sites has changed over the past six centuries. Finally, we suggest that the southern dome, with an ice thickness of $950 \mathrm{~m}$, is an ideal site from which to gain a climate history of the late stages of the last glacial and the deglaciation for comparison with the records from the deep Antarctic ice cores, and with other intermediate-depth cores such as Taylor Dome and Siple Dome.
\end{abstract}

\section{INTRODUGTION}

Lying to the south of the Weddell Sea, embedded between the Ronne and Filchner Ice Shelves, Berkner Island is the largest Antarctic island (Fig. 1). Roughly kidney-shaped, it rises to two domes approximately $140 \mathrm{~km}$ apart: Reinwarthhöhe in the north at $720 \mathrm{~m}$ a.s.l., and Thyssenhöhe in the south at $890 \mathrm{~m}$, separated by a trough, the McGarthy Inlet. The island has no rock outcrops, and an almost ideal topography for ice-core drilling, with shallow slopes leading to the domes, and relatively flat bedrock a little below sea level over much of its base. The meteorology of the island is mainly influenced by synoptic-scale weather systems, and is relatively unaffected by katabatic flow from the main Antarctic plateau to the south and east (Reijmer and others, 1999).

The first shallow firn cores (to $11 \mathrm{~m}$ depth) were drilled on the north and south domes of Berkner Island in 1990 (Wagenbach and others, 1994). Clear seasonal cycles in both the stable isotopes and some chemical species were evident, and it was noted that these two domes appeared to provide ideal sites for longer-term climate records. The Alfred Wegener Institute (AWI) and the British Antarctic Survey (BAS) developed a joint project to recover deeper ice cores from the two domes in 1995, achieving depths of 151 and $181 \mathrm{~m}$ at the two domes. Here we report the longer isotopic and chemical records these ice cores revealed, together with the borehole temperature

* Present address: Rutherford Appleton Laboratory, Didcot, Oxfordshire OX11 0QX, England.

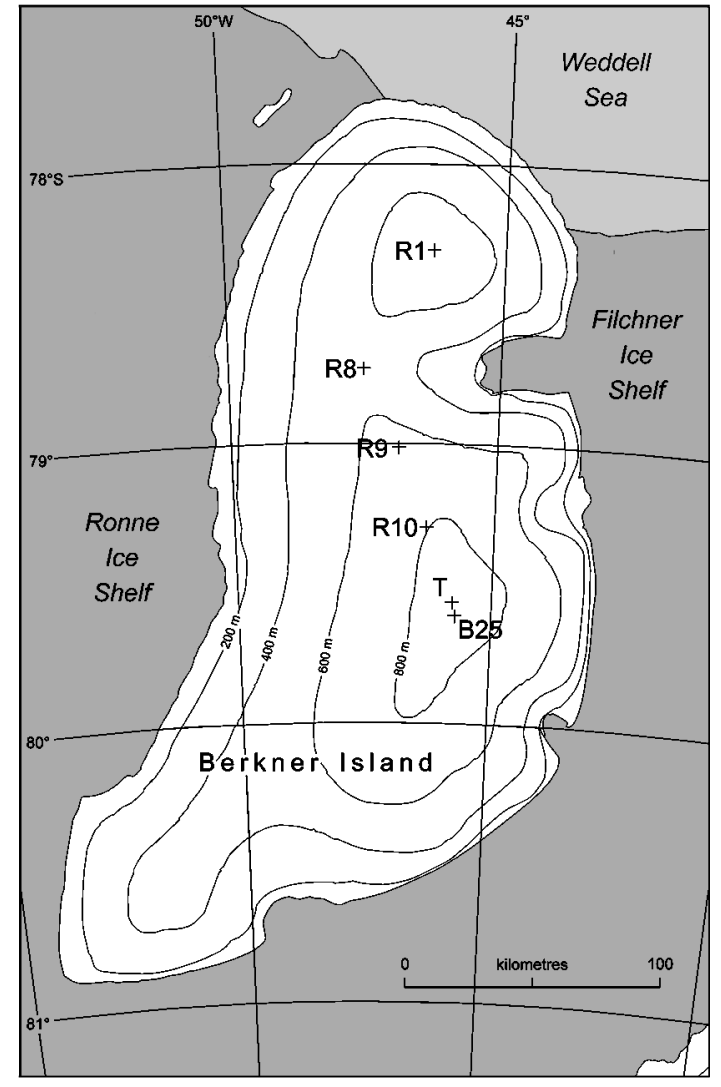

Fig. 1. Map showing the drilling sites on Berkner Island: R1 and B25 are the medium-depth cores described in this paper; $R 8-R 10$ are shallow cores; $T$ indicates the true southern dome summit in relation to the core. 


\begin{tabular}{|c|c|c|}
\hline & $\begin{array}{c}\text { North dome } \\
\text { (Reinwarthhöhe) }\end{array}$ & $\begin{array}{l}\text { South dome } \\
\text { (Thyssenhöhe) }\end{array}$ \\
\hline Location & $\begin{array}{l}78^{\circ} 18.45^{\prime} \mathrm{S} \\
46^{\circ} 16.37^{\prime} \mathrm{W}\end{array}$ & $\begin{array}{l}79^{\circ} 34.00^{\prime} \mathrm{S} \\
45^{\circ} 46.90^{\prime} \mathrm{W}\end{array}$ \\
\hline Elevation & $718 \mathrm{~m}$ & $890 \mathrm{~m}$ \\
\hline Ice thickness $^{1}$ & $990 \mathrm{~m}$ & $947 \mathrm{~m}$ \\
\hline Ice-core designation & $\mathrm{R} 1$ & B25 \\
\hline Position of core & $\begin{array}{l}\text { As above, centred on } \\
\text { dome summit }\end{array}$ & $\begin{array}{c}79^{\circ} 36.85^{\prime} \mathrm{S} \\
45^{\circ} 43.46^{\prime} \mathrm{W}\end{array}$ \\
\hline Length of core & $151 \mathrm{~m}$ & $\begin{array}{c}5 \mathrm{~km} \text { south of dome summit } \\
181 \mathrm{~m}\end{array}$ \\
\hline Age at core bottom & $\sim 600$ years & $\sim 1200$ years \\
\hline $10 \mathrm{~m}$ temperature & $-24.1^{\circ} \mathrm{C}$ & $-26.1^{\circ} \mathrm{C}$ \\
\hline $\begin{array}{l}\text { Mean accumulation } \\
\text { over full core }^{2}\end{array}$ & $204 \pm 7 \mathrm{~kg} \mathrm{~m}^{-2} \mathrm{a}^{-1}$ & $128 \pm 4 \mathrm{~kg} \mathrm{~m}^{-2} \mathrm{a}^{-1}$ \\
\hline
\end{tabular}

${ }^{1}$ Taken from Steinhage and Blindow (1995).

${ }^{2}$ Confidence interval at 99\% level.

records, and concur with the earlier study that Berkner Island is a good site for obtaining a climate record of the late glacial period, the deglaciation and the Holocene.

\section{METHODOLOGY}

The drilling activities on the two domes of Berkner Island (Fig. 1) were supported by the logistic operations of the two institutes involved. The drilling teams were transported to the sites by BAS Twin Otter and AWI Dornier DO228-100 aircraft since overland access to the island is made difficult by heavy crevassing on the margins. The U.K. effort centred on the northern dome, Reinwarthhöhe, where an ice core (we refer to this core as "Rl") to a depth of $151 \mathrm{~m}$ was drilled in January 1995. The AWI effort centred on a site $5 \mathrm{~km}$ to the south of the southern dome, Thyssenhöhe, where a $181 \mathrm{~m}$ core (referred to as "B25") was drilled in February 1995, together with a second $104 \mathrm{~m}$ core ("B24"). Each of these cores was drilled in dry boreholes using an electromechanical drill. The density log of the B25 core is given by Gerland and others (1999). At both sites, complementary shallow cores were taken to assess the spatial characteristics of the deposition, while a series of three $20 \mathrm{~m}$ cores (R8-R10) were collected during an overland traverse connecting the two sites. Table 1 describes the geographic location of the two main cores, and some of the derived physical features.

Temperature profiles down the full length of both boreholes were made several days after drilling using a string of ten Betatherm Corporation BetaCurve 3K3Al thermistors attached at $5 \mathrm{~m}$ intervals to a 12 -core cable. The string was lowered at intervals, left for several hours, then the thermistor resistances logged every $10 \mathrm{~s}$ using a Campbell Scientific 21X logger, exciting each thermistor with a $250 \mathrm{mV}$ current, and measuring the resistance $0.1 \mathrm{~s}$ after switching off the excitation voltage to minimize self-heating. Measurements continued until the readings had stabilized.

Cores were shipped frozen to Europe for analysis in the associated laboratories. In general, samples were cut from the cores to represent annual layers (as defined by the ECM record; see later), with many sections selected for sampling at sub-annual resolution (about 8-12 samples per annual layer). The range of anions and cations was measured by typical ion-chromatography techniques, using Dionex instruments

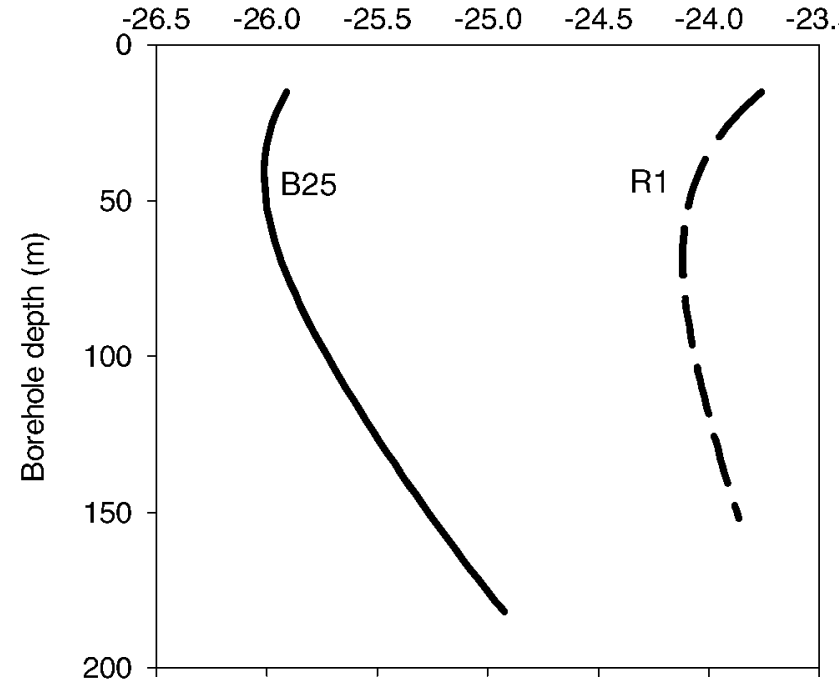

Fig. 2. Borehole temperature profiles: plotted here are the best-fit quadratic lines used in the model to estimate the bed temperature.

and columns (a summary of the procedures and typical accuracy of the techniques is included in Littot and others, 2002). At BAS, the stable-isotopes ratios along the $\mathrm{R} 1$ core were measured on a VG SIRA 10 dual-inlet mass spectrometer and Isoprep 18, in conjunction with laboratory standards calibrated against Vienna Standard Mean Ocean Water (VSMOW) and Standard Light Antarctic Precipitation (SLAP). Results are reported in the usual $\delta$ notation in per mil vs VSMOW; analytical precision is typically better than $\pm 0.1 \%$ or $\delta^{18} \mathrm{O}, \pm 1 \%$ for $\delta \mathrm{D}$. At GSF, Germany, the stableisotope ratios on the $\mathrm{B} 25$ core were measured on delta $\mathrm{D}$ and delta S dual-inlet mass spectrometers (Finnigan MAT), using standard methods for the preparation of the measuring gases; the standardization and the analytical accuracy are the same as at the BAS laboratory.

\section{RESULTS AND DISGUSSION}

\section{Temperature regime}

Figure 2 shows the temperature profile from each site and reveals the coldest temperatures at about $50-70 \mathrm{~m}$, with a slight warming towards the surface (the disturbance to the profile in the upper $15 \mathrm{~m}$ due to seasonal effects has been removed from the figure). This suggests the mean annual temperature is now about $0.5-1.0^{\circ} \mathrm{C}$ warmer than in the recent past; we have not yet quantified the time-scale, but believe the warming has taken place over the past few decades. The $10 \mathrm{~m}$ temperature was measured as $-24.1{ }^{\circ} \mathrm{C}$ at the northern dome, and $-26.1^{\circ} \mathrm{C}$ at the higher southern dome. These measurements are some $1.5^{\circ} \mathrm{C}$ colder than reported by Wagenbach and others (1994), but they did note that their measurements were made too soon after drilling and should be considered upper limits. The intermediate $20 \mathrm{~m}$ drilling sites, spaced at approximately $50 \mathrm{~km}$ intervals between the two domes, resulted in $10 \mathrm{~m}$ temperatures of $-24.8^{\circ},-24.6^{\circ}$ and $-25.3^{\circ} \mathrm{C}(\mathrm{R} 8-$ R10 in Fig. 1). While the longer profiles (Fig. 2) suggest the $10 \mathrm{~m}$ temperature may give a slightly low estimate of the true mean annual temperature, it is interesting to compare these values with those recorded in a series of shallow boreholes across the Filchner-Ronne Ice Shelf (Mayer and others, 1995). The ice-shelf measurements at a similar latitude or dis- 

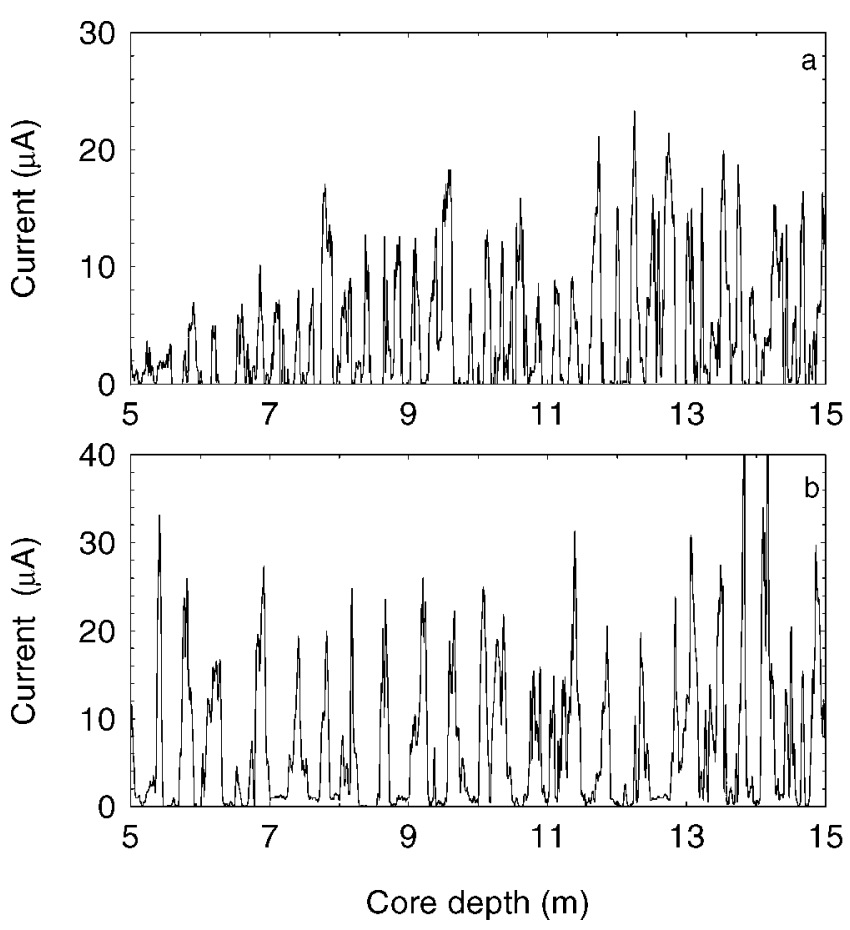

Fig. 3. Example sections of the ECM profiles from the two cores: (a) south dome B25 core; (b) north dome R1 core, showing fewer years due to higher accumulation rate.

tance from the Weddell Sea, and $700 \mathrm{~m}$ lower in altitude than those on Berkner Island, were all in the range $-26^{\circ}$ to $-30^{\circ} \mathrm{C}$. We accept that borehole temperatures from ice shelves have less validity as a proxy for the mean annual temperature than borehole temperatures taken on grounded ice, but note that the general observation of temperatures at the surface of the ice shelf similar to those on the summit of Berkner Island is borne out by the mean stable-isotope data from the cores (mean $\delta^{18} \mathrm{O}$ for the $\mathrm{R} 1$ core is $-25.5 \%$, for the $\mathrm{B} 25$ core $-28.1 \%$, while Graf and others (1999) give values for $\delta^{18} \mathrm{O}$ in the range $-26 \%$ to $-29 \%$ for the ice-shelf cores at a similar latitude). Taking the ice-shelf measurements as reference and applying a dry adiabatic lapse rate suggests the temperatures on the ice cap are about $7^{\circ} \mathrm{C}$ higher than expected, possibly indicating a persistent temperature inversion over Berkner Island. Thus, any long-term changes in either measured temperature, or temperatures derived from isotopes, are susceptible to changes in the strength or persistence of the inversion.

Based on the borehole temperature profiles, a simple model, taking into account the best estimates of accumulation rate, steady surface altitude and an estimate of the geothermal heat flux (we used $50 \mathrm{~mW} \mathrm{~m}^{-2}$ ) gives approximate bed temperatures of $-12.4^{\circ} \mathrm{C}$ at the northern dome, and $-11.8^{\circ} \mathrm{C}$ at the southern dome.

\section{Dating the ice cores}

Electrical measurements of the full cores were made in the field shortly after collection using an electrical bench designed to measure both the dielectric profiling (DEP) and electrical conductivity measurement (ECM) profiles. DEP measures the conductance and capacitance at a number of $\mathrm{AC}$ frequencies and responds in a complex manner to both acidity and dissolved neutral ions (Moore and others, 1990), and often displays both seasonal cycles and clear volcanic horizons. On Berkner Island, we used a single frequency $(50 \mathrm{kHz})$ and a $10 \mathrm{~mm}$ resolution to measure complete profiles of both cores. Unfortunately, the profile proved poor
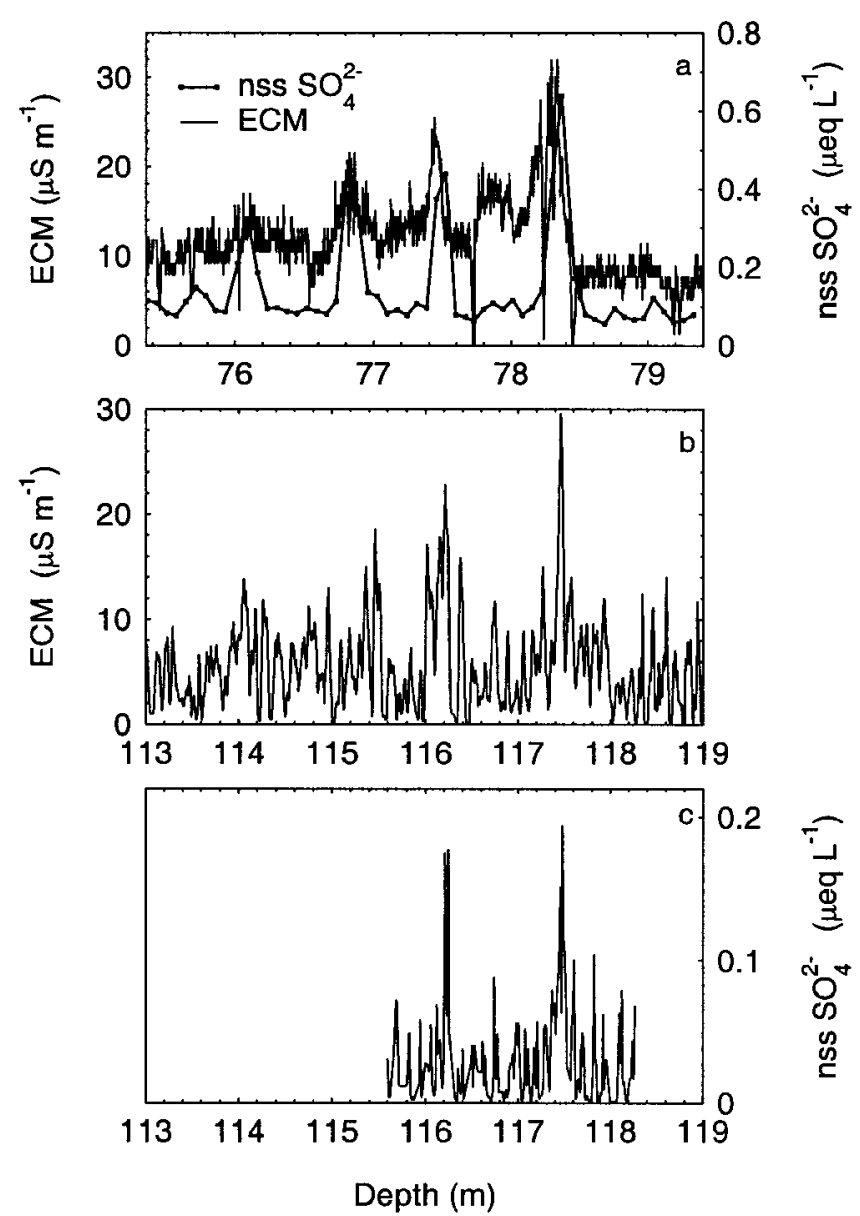

Fig. 4. The 1259 sequence of four volcanic peaks: (a) example from a well-dated Dronning Maud Land core, where the amplitude of the seasonal biogenic sulphate is low, resulting in a greater contrast compared with the Berkner core; $(b)$ the ECM record from B25 for the same period, with the depth scaled to cover the same time period as (a); (c) the available non-sea-salt sulphate data from B25.

at distinguishing seasonal cycles in these cores. We attribute this to the poor design of this particular instrument, use of a single frequency rather than a range of frequencies, and the phasing of the chemical species that contribute to the signal, with acidity peaking in summer, while the bulk sea-water components appear to peak in winter (Wagenbach and others, 1994). The ECM measures the current passing across the core between two electrodes at a high DC voltage, and responds mainly to acidity in the ice (Hammer, 1983). The ECM profile was measured on both Berkner cores with a resolution of $3 \mathrm{~mm}$. Strong seasonal cycles in sulphuric acid of marine biogenic origin give clear annual cycles in the records from both cores, with sporadic peaks from acidity of volcanic origin.

The clarity of the ECM record (Fig. 3) allowed both cores to be dated by layer counting. Occasionally, sections proved ambiguous, and here corroboration was found in the chemical records where data were available. Although potentially acting as clear stratigraphic markers of known dates, the peaks of volcanic origin are less clear in these cores compared to many cores from central Antarctica due to competition with the similar-magnitude annual cycle. One characteristic of the volcanic peaks is a raised winter minimum in the ECM and non-sea-salt sulphate as the volcanic input continues, while the seasonal biogenic acidity reduces close to zero in normal years. Despite the lack of 


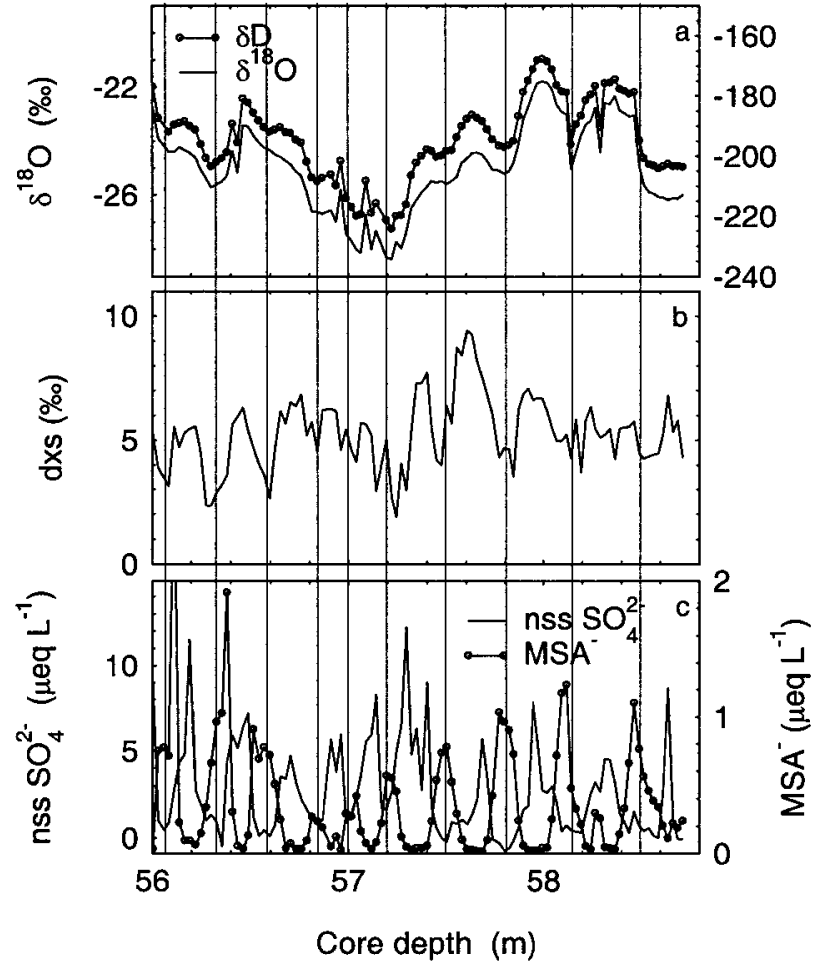

Fig. 5. Seasonal cycles in chemistry and isotopes from the R1 core close to the point of pore close-off: (a) the stable isotopes; (b) the derived dxs parameter (see text for derivation); (c) methanesulphonate, and nss $\mathrm{SO}_{4}^{2}$ which is mostly of marine biogenic origin in years without volcanic influence. Vertical lines indicate the annual layers, with the line located at the lowest point in the nss $\mathrm{SO}_{4}^{2}$ curve, taken to be mid-winter.

clarity, we can make out some of the largest volcanoes of the past millennium in the ECM, and have compared these sections with the record of non-sea-salt sulphate, and we are confident in our identification of these events. We can therefore use these horizons to check our continuous layer-counting dates. The deepest sequence of volcanic events seen in the $\mathrm{B} 25$ core is the series of volcanoes around 1259. This is a commonly observed sequence of four events, spaced about 10 years apart (e.g. Langway and others, 1995). In Figure 4, the sequence is compared with the same period in an ice core from Dronning Maud Land (collected by BAS in 1998 at position $77^{\circ} 03^{\prime} \mathrm{S}, 10^{\circ} 30^{\prime} \mathrm{W}$ ) which has a much higher contrast between the volcanic peaks and the seasonal signal, and allows us to compare the pattern of acidic deposition with a non-coastal site that is $<500 \mathrm{~km}$ from Berkner and likely to fall under a comparable long-range volcanic influence. The pattern in the electrical measurements from the two cores is broadly similar: four peaks, descending in size from the oldest, and spaced about equally in depth. We assumed the lowest peak to be dated 1259, a commonly found date in the literature, and forced our layer counting to this point. The dates for the four peaks then become $1284,1275,1268$ and 1259, broadly similar to the dates given by Langway and others (1995) for South Pole of 1285, 1277, 1269 and 1259 and for "NBY89" of 1287, 1278, 1270 and 1259. In the B25 core, we can also detect the signal of the 1815 Tambora (Indonesia) eruption, together with the associated peak in about 1809, and the Kuwae (Vanuatu) eruption often attributed to the year 1454. Using these horizons to constrain our layer counting results in a dating accuracy to a possible maximum of \pm 5 years between horizons. In the section older than 1259, we have no well-dated horizons,

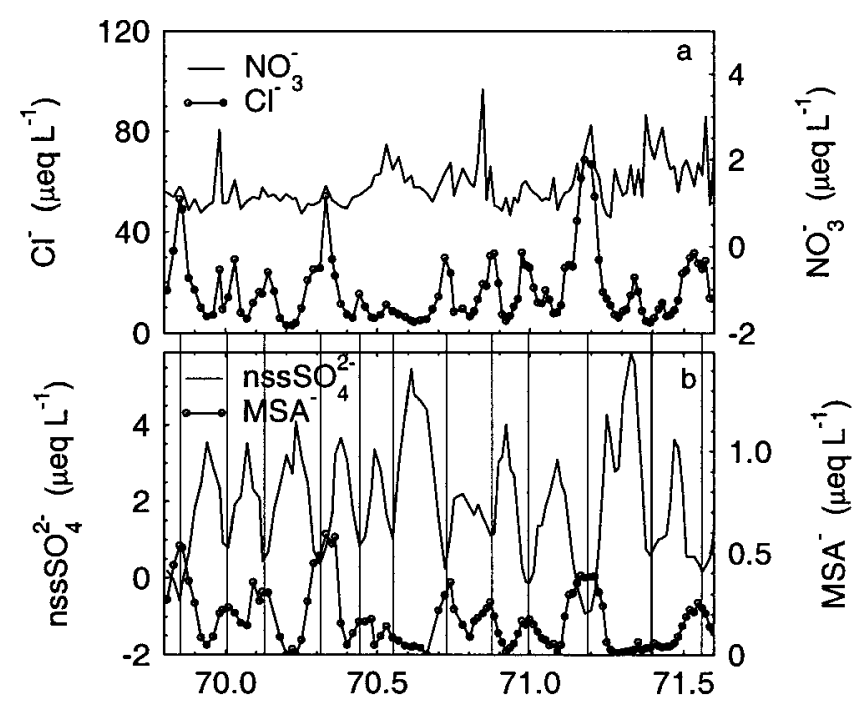

Core depth $(m)$

Fig. 6. Seasonal cycles in chemistry and isotopes from the B25 core below the point of pore close-off: ( a) $\mathrm{NO}_{3}$ and $\mathrm{Cl}$; ( $b$ ) the marine biogenic sulphur species. Vertical lines indicate the annual layers, with the line located at the lowest point in the nss $\mathrm{SO}_{4}^{2}$ curve taken to be mid-winter.

and we estimate the dating error could be up to \pm 15 years by the oldest ice, about AD 800 . Unfortunately, the R1 core from the higher-accumulation northern dome site does not reach back as far as the distinctive 1259 sequence of eruptions, and we cannot make out the 1454 Kuwae horizon which appears to have fallen in a damaged section of core. We can discern the pair of events attributed to the Tambora eruption and an unknown volcano (1809), and the influence of Krakatoa, Indonesia, in 1883. We use these horizons to constrain the layer counting. Though we may accumulate errors deeper in the $\mathrm{R} 1$ core, it does benefit from clearer annual layers in the ECM. Thus we estimate that the dating error may be as much as \pm 15 years by the deepest point reported here of around AD 1400.

\section{Seasonal signal}

Wagenbach and others (1994) described the seasonal cycles in both chemistry and stable isotopes from the upper $10 \mathrm{~m}$ of the north and south dome sites. Non-sea-salt sulphate $\left(\mathrm{nssSO}_{4}{ }^{2-}\right)$ shows a clear seasonal cycle, peaking in the summer months. (In this study, $\mathrm{nssSO}_{4}{ }^{2-}$ has been calculated with reference to $\mathrm{Na}$ as the sea-salt marker, but using a factor half the normal bulk sea water to account for fractionation during the formation of the aerosol (Rankin and others, 2000); this factor is similar to that derived for this region by Minikin and others (1994).) In their $10 \mathrm{~m}$ cores, Wagenbach and others (1994) also show clear seasonality in methanesulphonate $\left(\mathrm{MSA}^{-}\right)$, nitrate $\left(\mathrm{NO}_{3}{ }^{-}\right)$and $\delta \mathrm{D}$ which all reach a maximum in the summer snow layer, while chloride $\left(\mathrm{Cl}^{-}\right)$, derived from marine aerosol, peaks in the winter. They note, though, that there was some evidence in their $10 \mathrm{~m}$ cores of post-depositional effects disturbing the seasonality of $\mathrm{MSA}^{-}$, which may migrate in the firn to the winter layer (Mulvaney and others, 1992; Pasteur and Mulvaney, 2000), and of $\mathrm{NO}_{3}{ }^{-}$, which is commonly found to be re-emitted from the snow after deposition (Jones and others, 2001; Röthlisberger and others, 2002). They also note a substantial decrease in the amplitude of the seasonal $\delta \mathrm{D}$ signal, due to efficient mass exchange by watervapour diffusion. 

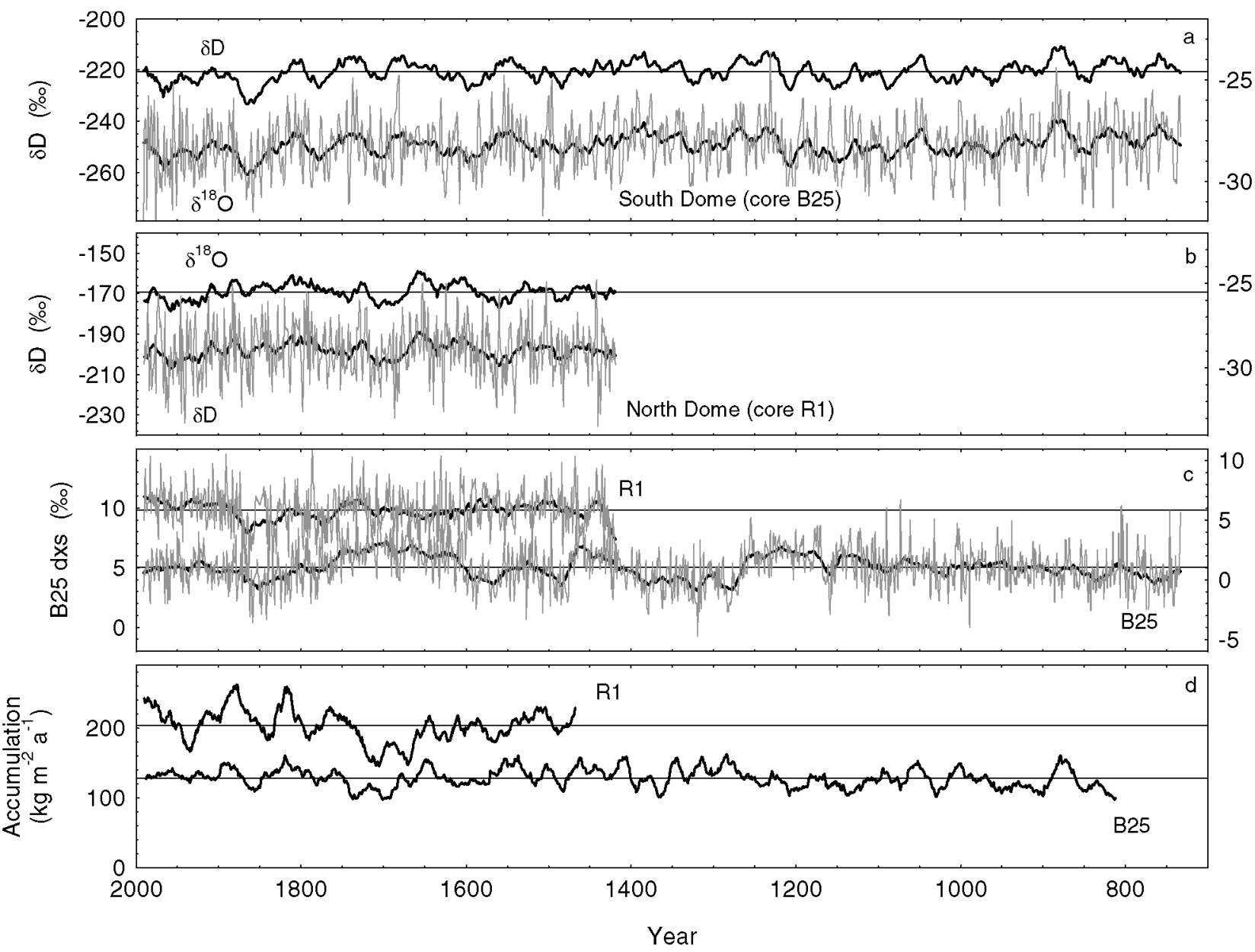

Fig. 7. The primary climate parameters: the accumulation rate, the stable isotopes as a proxy for temperature, and deuterium excess (dxs see text for derivation) associated with characteristics of the moisture source region. (a) The B25 core data: the upper line is the $\delta D$ smoothed with a 21 year filter (mean-221\%o); the lower line combines the annual $\delta^{18} O$ signal plus the 21 year smoothed profile (mean-28.2\%); ( $b$ ) the R1 core data: the upper line is the $\delta^{18} \mathrm{O}$ smoothed with a 21 year filter (mean-25.5\%), and the lower line combines the annual $\delta D$ signal plus the 21 year smoothed profile (mean-198\%o); (c) the dxs from both R1 (upper line, mean -5.84\%) and B25 (lower line, mean-5.04\%), both annual data and 21 year smoothed profiles; $(d)$ the 21 year smoothed accumulation rate from $R 1$ ( upper line, mean $204 \mathrm{~kg} \mathrm{~m}^{-2} a^{-1}$ ) and B25 (lower line, mean $128 \mathrm{~kg} \mathrm{~m}^{-2} a^{-1}$ ). (Accumulation data are calculated from the winter depth horizons deduced from the ECM record, corrected for density and for thinning. Since the cores penetrated only the upper 10-15\% of the ice-sheet depth, we used a simple Nye model ( Nye, 1963), which assumes linear vertical strain rate through the total depth, and an ice sheet frozen to the bed.)

Taking the seasonal profiles from the two deep cores, we see the change in the seasonal signal for some species continuing deeper. In Figure 5 (data from the north dome Rl core) the $\mathrm{nssSO}_{4}{ }^{2-}$ continues to show a strong seasonal cycle, and we consider this a conservative marker of the summer layer. $\mathrm{MSA}^{-}$has migrated entirely to the winter layer and is virtually absent now in the summer layer where it was originally deposited. The nature of this migration is discussed more fully elsewhere (Pasteur and Mulvaney, 2000). Both the stable-isotope signals, $\delta \mathrm{D}$ and $\delta^{18} \mathrm{O}$, have largely lost their original clear seasonality, due to vapour transport and deposition. Intriguingly, despite the smearing of the individual stable-isotope profiles, there appears to be a seasonal component in the derived parameter deuterium excess $(\mathrm{dxs})$. Deuterium excess is calculated numerically by the simple relationship:

$$
\mathrm{dxs}=\delta \mathrm{D}-8 \delta^{18} \mathrm{O} .
$$

It has been suggested that dxs may be a proxy for the ocean temperature in the moisture source region, but Jouzel and Koster (1996) advise caution in interpreting change in dxs solely as changes in evaporative source temperature, and stress other factors such as relative humidity and wind speed. We speculate that our seasonal signal may be due to the seasonal change in source region of a combination of these factors. It is possible that there is a very high-amplitude seasonal dxs signal at the surface, and that this is weakened by diffusion but still survives at depth. However, the apparent seasonality could be a fortuitous consequence of the difference in diffusivities of $\delta \mathrm{D}$ and $\delta^{18} \mathrm{O}$. We have no surface high-resolution dxs data yet, but are currently making the measurements to test this idea.

We have no seasonal-resolution isotope data from the south dome B25 core to compare with the north dome R1 data, but we do find a similar pattern in the two biogenic sulphur species (Fig. 6), with the $\mathrm{nssSO}_{4}{ }^{2-}$ maintained as the conservative marker of the summer layer, but the $\mathrm{MSA}^{-}$confined to the winter layer. As noted by Wagenbach and others (1994), the sea-salt-derived $\mathrm{Cl}^{-}$at Berkner Island predominantly peaks in winter, and that seems unchanged at depth. In this figure, there appears a good correlation between the concentrations in $\mathrm{Cl}^{-}$and $\mathrm{MSA}^{-}$, but this appears to be fortuitous: regression analysis of $\mathrm{MSA}^{-}$on $\mathrm{Cl}^{-}$across this short section gives an $r^{2}$ value of 0.37 , but 


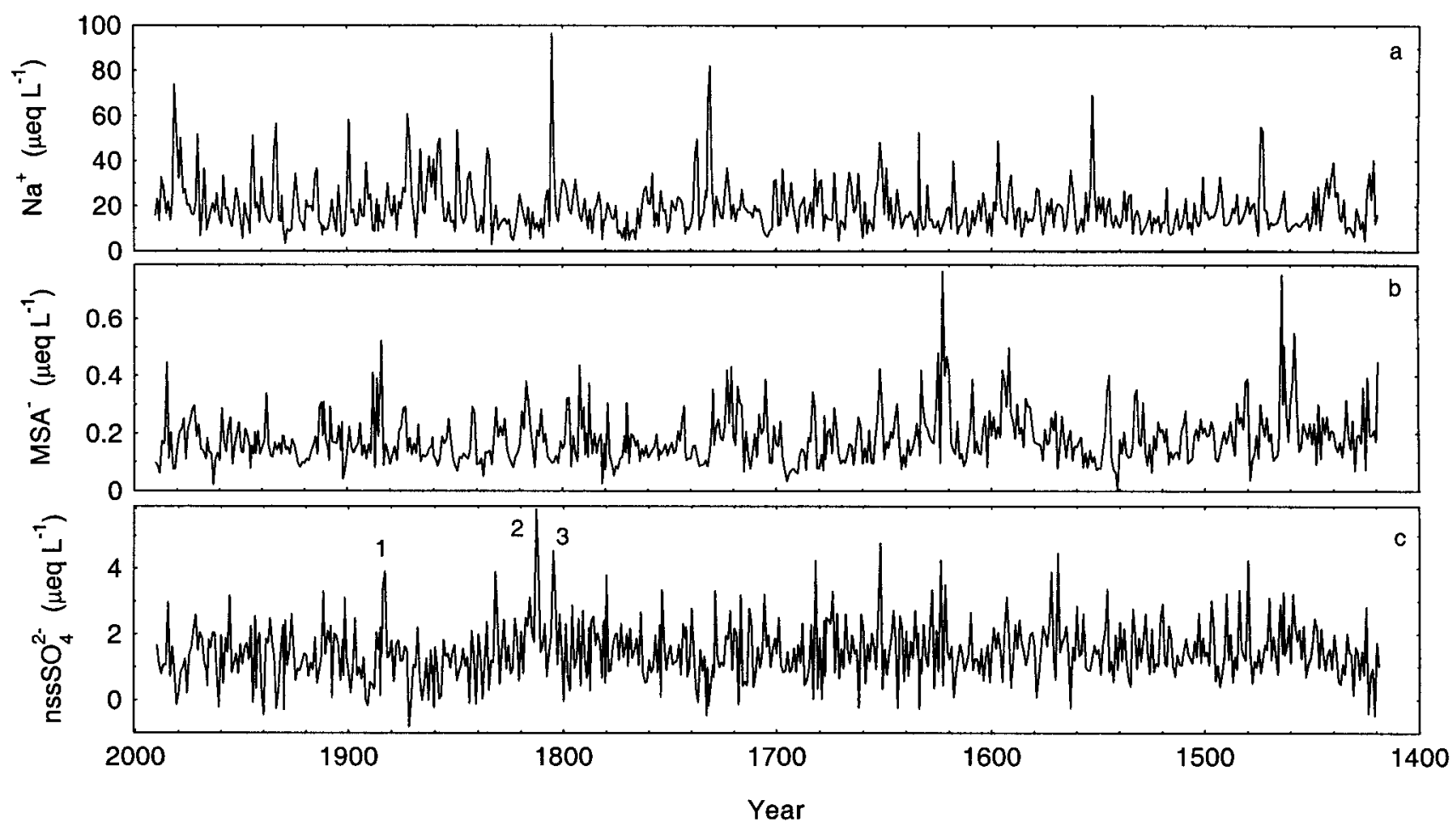

Fig. 8. Chemical profiles from the R1 core (annual data, no smoothing applied): (a) sodium;( b) methanesulphonate; (c) nonsea-salt sulphate. Three volcanic horizons are marked in (c):1. Krakatoa (1883), 2. Tambora (1815), 3. Unknown (1809).

across the full dataset gives $r^{2}$ as 0.14 , and the relationship is not significant. Finally, the $\mathrm{NO}_{3}{ }^{-}$appears to display rather poor seasonality, possibly as a result of the post-depositional losses this ion experiences, or smoothing through vapourphase diffusion (Röthlisberger and others, 2002).

\section{The climate record}

The main climate parameters from the two cores are detailed in Figure 7. There is little remarkable about the records from either site: no extended period stands out as being either warmer or cooler than the long-term average. Certainly, there do not appear to be periods that could be ascribed to either the Medieval Warm Period or Little Ice Age, as seen in Europe. There is apparently very poor correlation between the isotope records from the two sites, a point also made by Graf and others (2002) who find little correlation among stable-isotope records in the Weddell Sea region. Surprisingly then, there seems a greater similarity in the records of dxs and accumulation between the two sites. In the case of the dxs profile, both cores display a gradual decline from the early part of the 18th century to the mid19th century, before rising again to the mid-20th century. Although the moisture transport and local deposition-site meteorology results in quite different condensation histories, and therefore poor inter-site correlation in $\delta \mathrm{D}$ and $\delta^{18} \mathrm{O}$, we can conclude that the similar trend in the dxs signal indicates a common moisture source. However, the similarity in dxs breaks down earlier than 1700 , perhaps indicating that this was a period when the source region was different. There is also some resemblance in the accumulation profile measured at each site, again particularly through the 17 th to mid20th century. Neither core shows any long-term change in the accumulation, with the pattern being more one of a steady cycling on about a 50 year frequency between higher and lower accumulation than the mean.

\section{The long chemistry record}

The long chemistry record from the north dome R1 core (Fig. 8), included here for completeness, is rather lacking in character compared to longer ice cores that penetrate back into the glacial period. The dominance of the Weddell Sea can be seen in the very high levels of sea-salt species, with mean $\mathrm{Na}^{+}$ of $19.1 \mu \mathrm{eq} \mathrm{L} \mathrm{L}^{-1}$ and $\mathrm{Cl}^{-}$of $24.1 \mu \mathrm{eq} \mathrm{L} \mathrm{L}^{-1}$. The ratio $\mathrm{Cl} / \mathrm{Na}$ is 1.26 , a little higher than the standard sea-water ratio of 1.165, probably due to the fractionation and depletion of $\mathrm{Na}_{2} \mathrm{SO}_{4}$ from frost flowers which develop on freezing brine and probably form part of the aerosol source of the marine ions deposited in the winter ice (Rankin and others, 2000). The sea-salt species are largely deposited in winter, and the interannual variability seen in Figure 8 is more likely to be due to storm frequency than distance to open ocean. To the south, the influence of the open ocean is slightly lower, with a mean $\mathrm{Na}^{+}$in the B25 core of $11.0 \mu \mathrm{eq} \mathrm{L} \mathrm{L}^{-1}$, reflecting that it is $200 \mathrm{~km}$ from the edge of the Weddell Sea, compared to $50 \mathrm{~km}$ at the north dome. Both the marine biogenic sulphur species, $\mathrm{MSA}^{-}$and $\mathrm{nsSSO}_{4}{ }^{2-}$, are also slightly higher at the drill site closer to the sea-water edge, an indication of the gradual loss of aerosol from the air mass as it moves further from the ocean. In the long $\mathrm{nssSO}_{4}{ }^{2-}$ record, the signal is dominated by the seasonal component, and the input from long-range volcanic eruptions is difficult to pick out.

\section{GONGLUSIONS}

With a high accumulation rate, and relatively low wind speeds due to the lack of katabatic winds affecting the island, Berkner Island appears better placed to retain the seasonal signal in chemistry and stable isotopes than the deep icecore sites of central Antarctica. And this is indeed the conclusion from this study of medium-depth ice cores taken from the two island domes: most chemistry does retain a seasonal signal (though in the case of $\mathrm{MSA}^{-}$, not the original 
seasonality as laid down at the surface). This implies that, even with thinning due to burial, a seasonal signal should be recoverable in even the oldest ice, providing a direct measurement of accumulation. While the stable-isotope seasonal signal is largely lost due to vapour redistribution in the firn, there appears to be some seasonality left in the derived parameter dxs. Since the data presented here are from close to the pore close-off (about $60 \mathrm{~m}$ ) when vapour transport will cease, the signal may well be retained deep into the ice sheet, allowing estimates of changes in seasonal moisture source to be made on older ice, potentially even into the pre-Holocene period. We have found the longerterm isotope, accumulation and chemical profiles to be largely devoid of excitement, varying around a stable mean.

Taking these observations into account, we agree with the observation of Wagenbach and others (1994) that Berkner Island, particularly the southern dome, with nearly $1000 \mathrm{~m}$ of ice depth over a bedrock topography devoid of mountains, an accumulation of about $130 \mathrm{~kg} \mathrm{~m}^{-2} \mathrm{a}^{-1}$, a bed temperature of about $-12{ }^{\circ} \mathrm{C}$ and a near-perfect stratigraphic column (evidenced by the clear internals layers in radio-echo reflection profiles reported by Steinhage and Blindow (1995)), would make an ideal location for a deep ice core to capture the long climate record of the region, potentially back to the Last Glacial Maximum (LGM). Model estimates of the depthage relationship assuming steady isothermal flow (personal communication from R. Hindmarsh, 2001) predict that the transition will be at about $250 \mathrm{~m}$ above the bed, and a potential age of $>30000$ years near to the bed.

It is known that long-term climate change at inland Antarctic sites (Byrd, Vostok) is out of phase with Greenland: the Antarctic Cold Reversal, for example, precedes the Younger Dryas in Greenland (Sowers and Bender, 1995; Blunier and others, 1997). However, results reported from Taylor Dome, near the Antarctic coast, have cast doubt on this simple pattern, suggesting that at this site the pattern of deglaciation is broadly in phase with Greenland, rather than central Antarctica (Steig and others, 1998, 2000). Although the detail of the timing of the deglaciation of the Taylor Dome core has been questioned (Mulvaney and others, 2000), this apparent discontinuity with central Antarctic records poses severe tests on existing models of climate change, which have focused on the role of the Atlantic circulation in transferring heat between the hemispheres and have generally sought to explain the phasing of Northern/Southern Hemisphere response assuming each polar region responds coherently. A climate record of the deglaciation period from a coastal site facing the South Atlantic Ocean is an obvious choice in gaining further insight into the spatial pattern of the phasing. The Berkner Island ice cap is the best site in the Antarctic Peninsula/Weddell Sea region for obtaining a high-resolution climate record for the period from the LGM through to the Holocene. Finally, in addition to the record of climate change through the deglaciation, we note that a core from this location will finally provide the answer to the glaciological question of when Berkner Island emerged from the overlying West Antarctic ice sheet to become an independent dome, since it should be clear from the chemical analyses when we reach ice that has flowed from the inland ice sheet, rather than deposited directly onto the Berkner dome.

\section{ACKNOWLEDGEMENTS}

We acknowledge the field teams who contributed to the successful drilling season in 1995: S. Garrod, S. Gerland, C. Lukeit, M. Nolting, F. Töppe, D. Steinhage and the late U. Weigel.

\section{REFERENGES}

Blunier, T. and 9 others. 1997. Timing of the Antarctic cold reversal and the atmospheric $\mathrm{CO}_{2}$ increase with respect to the Younger Dryas event. Geophys. Res. Lett., 24(21), 2683-2686.

Gerland, S., H. Oerter, J. Kipfstuhl, F. Wilhelms, H. Miller and W. D. Miners. 1999. Density log of a $181 \mathrm{~m}$ long ice core from Berkner Island, Antarctica. Ann. Glaciol., 29, 215-219.

Graf, W., O. Reinworth, H Oerter, C. Mayer and A. Lambrecht. 1999. Surface accumulation on Foundation Ice Stream, Antarctica. Ann. Glaciol., 29, 215-219.

Graf, W. and 6 others. 2002. Stable-isotope records from Dronning Maud Land, Antarctica. Ann. Glaciol., 35 (see paper in this volume).

Hammer, C. U. 1983. Initial direct current in the buildup of space charges and the acidity of ice cores. 7. Phys. Chem., 87(21), 4099-4103.

Jones, A. E. and 6 others. 2001. Measurements of $\mathrm{NO}_{\mathrm{x}}$ emissions from the Antarctic snowpack. Geophys. Res. Lett., 28 (8), 1499-1502.

Jouzel, J. and R. D. Koster. 1996. A reconsideration of the initial conditions used for stable water isotope models. 7. Geophys. Res., 101(D17), 22,933-22,938.

Langway, C. C., Jr, K. Osada, H. B. Clausen, C. U. Hammer and H. Shoji. 1995. A 10-century comparison of prominent bipolar volcanic events in ice cores. 7. Geophys. Res., 100 (D8), 16,241-16,247.

Littot, G. C. and 9 others. 2002. Comparison of analytical methods used for measuring major ions in the EPICA Dome $\mathrm{C}$ (Antarctica) ice core. Ann. Glaciol., 35 (see paper in this volume).

Mayer, C., A. Lambrecht and H. Oerter. 1995. Glaciological investigations on the Foundation Ice Stream. In Oerter, H., ed. Filchner-Ronne Ice Shelf Programme (FRISP). Report No. 9 (1995). Bremerhaven, Alfred Wegener Institute for Polar and Marine Research, 57-63.

Minikin, A., D. Wagenbach, W. Graf and J. Kipfstuhl. 1994. Spatial and seasonal variations of the snow chemistry at the central Filchner-Ronne Ice Shelf, Antarctica. Ann. Glaciol., 20, 283-290.

Moore, J. C., J. G. Paren and R. Mulvaney. 1990. Chemical evidence in polar ice cores from dielectric profiling. Ann. Glaciol., 14, 195-198.

Mulvaney, R., E. C. Pasteur, D. A. Peel, E. S. Saltzman and P.-Y. Whung. 1992. The ratio of MSA to non-sea-salt sulphate in Antarctic Peninsula ice cores. Tellus, 44B(4), 295-303.

Mulvaney, R. and6 others. 2000. The transition from the last glacial period in inland and near-coastal Antarctica. Geophys. Res. Lett., 27(17), 2673-2676.

Nye, J. F. 1963. Correction factor for accumulation measured by the thickness of the annual layers in an ice sheet. F. Glaciol., 4 (36), 785-788.

Pasteur, E. and R. Mulvaney. 2000. Migration of methane sulphonate in Antarctic firn and ice. F. Geophys. Res., 105(D9), 11,525-11,534.

Rankin, A. M., V. Auld and E.W. Wolff. 2000. Frost flowers as a source of fractionated sea salt aerosol in the polar regions. Geophys. Res. Lett., 27(21), 3469-3472.

Reijmer, C., W. Greuell and J. Oerlemans. 1999. The annual cycle of meteorological variables and the surface energy balance on Berkner Island, Antarctica. Ann. Glaciol., 29, 49-54.

Röthlisberger, R. and10 others. 2002. Nitrate in Greenland and Antarctic ice cores: a detailed description of post-depositional processes. Ann. Glaciol. 35 (see paper in this volume).

Sowers, T. and M. Bender. 1995. Climate records covering the last glaciation. Science, 269(5221), 210-214.

Steig, E. J. and 8 others. 1998. Synchronous climate changes in Antarctica and the North Atlantic. Science, 282(5386), 92-95.

Steig, E. J. and 7 others. 2000. Wisconsinan and Holocene climate history from an ice core at Taylor Dome, western Ross Embayment, Antarctica. Geogr. Ann., 82A(2-3), 213-235.

Steinhage, D. and N. Blindow. 1995. First results of short pulse radio echo sounding on the top of Berkner Island. In Oerter, H., comp. FilchnerRonne Ice Shelf Programme (FRISP). Report No. 9 (1995). Bremerhaven, Alfred Wegener Institute for Polar and Marine Research, 123-126.

Wagenbach, D. and 6 others. 1994. Reconnaissance of chemical and isotopic firn properties on top of Berkner Island, Antarctica. Ann. Glaciol., 20, 307-312. 